\title{
Experts online: An analysis of trading activity in a public Internet chat room
}

\author{
Bruce Mizrach*, Susan Weerts \\ Department of Economics, Rutgers University, New Brunswick, NJ 08901, United States
}

\section{A R T I C L E I N F O}

\section{Article history:}

Received 25 October 2006

Received in revised form 2 February 2009

Accepted 4 February 2009

Available online $\mathrm{xxx}$

\section{JEL classification:}

G14

G20

\section{Keywords:}

Behavioral finance

Day trading

Familiarity bias

Disposition effect

Experts

\begin{abstract}
A B S T R A C T
We analyze the trading activity in an Internet chat room over a 4-year period. The data set contains nearly 9000 trades from 676 traders. We find these traders are more skilled than retail investors analyzed in other studies. 55 percent make profits after transaction costs, and they have statistically significant $\alpha$ s of 0.17 percent per day after controlling for the Fama-French factors and momentum. Traders hold their winners 25 percent longer than their losers. 42 percent trade both long and short, with equal success rates, and almost double the profit per trade when short. The estimates show a strong influence from other traders, with a buy (sell) order 40.7 percent more likely to be of the same sign if there has been a recent post. Traders improve their skill over time, earning an extra $\$ 189$ per month for each year of trading experience. They also gain expertise in trading particular stocks. Traders who raise their Herfindahl index by 0.1 raise their profitability by $\$ 46$ per trade.
\end{abstract}

(c) 2009 Elsevier Ltd. All rights reserved.

\section{Introduction}

The individual investor has been carefully scrutinized in the growing literature on behavioral finance. These studies typically document the underperformance of the do-it-yourself trader. Barber and Odean (2000) find, in a large sample of households from a major discount stock broker, annual average returns trail the market benchmarks by nearly 200 basis points. The most active quintile of traders has the lowest returns, underperforming the market by more than 700 basis points. Barber and Odean conclude that "trading is hazardous to your wealth."

Day traders, who, as the SEC defines, "rapidly buy and sell stocks throughout the day," fare no better than retail investors. Barber et al. (2009) study a large sample of day traders in Taiwan and document that over 80 percent lose money. Jordan and Diltz (2003) found 73.4 percent of the 334 traders they studied in 1998 and 1999 at a national brokerage firm had negative net profits. The traders lost almost $\$ 8000$ on average.

Odean (1999) and Barber and Odean (2000) attribute poor performance to excessive trading. Overconfidence, Odean (1998) observes, leads investors to overestimate their own knowledge about a security. This leads to divergent views about fundamental values, that in turn motivates trading, despite the fact that trading lowers their expected utility. Graham et al. (2005) identify a competence effect which makes investors more willing to act upon their self-perceived skill. Competence, they find, leads to greater international diversification, but it also increases trading frequency.

\footnotetext{
* Corresponding author.

E-mail address: mizrach@econ.rutgers.edu (B. Mizrach).
} 
A tendency to sell winners quickly and hold onto losers, the disposition effect of Shefrin and Statman (1985), also leads to underperformance. This psychological bias appears in the traders studied by Odean (1999) and Grinblatt and Keloharju (2001). Genesove and Mayer (2001) document similar loss aversion in the housing market.

Other studies have attributed underperformance to poor stock selection. Goetzmann and Kumar's (2004) retail traders are underdiversified. Barber and Odean (2008) observe a tendency to buy attention grabbing stocks. Investors in Barber et al. (2006) overweight past returns, which they attribute to Kahneman and Tversky's (1974) representativeness heuristic. Stock selection, Huberman (2001); Massa and Simonov (2005), and Amadi (2004) have noted, is subject to familiarity bias, a tendency to pick the same stocks again and again. An excellent survey of this literature is by Barberis and Thaler (2003).

A distinct feature of retail traders is their unwillingness to take short positions. Angel et al. (2003) found that only 1 in 42 trades on NASDAQ is a short sale. In Barber and Odean (2008) only 0.29 percent of the more than 66,000 traders in the room take short positions. We will break out many of our results into short and long trades.

There is also evidence that traders of all types can learn over time and improve their performance. Barber et al. (2009) identify a select group of approximately 1300 traders who consistently earn profits. Coval et al. (2005) find that the top 10 percent of investors make persistent abnormal profits. Niccolosi et al. (forthcoming) observe that individual investors learn about their trading skill and increase their trades and profits in subsequent periods. Kaniel et al. (2008) also show that, in the aggregate, individual investors may be smart money: excess returns are positive (negative) in the month after intense buying (selling) by individuals.

This paper studies a group of active traders who voluntarily post their trades in real time into a public Internet chat room called Activetrader. We rely on a previously unexplored data set of chat room logs compiled by the first author over a 4 -year period. We analyze the trading activity in four 1-month snapshots from 2000 to 2003.

The authors surveyed the chat room participants, and this paper helps clarify the portrait of the individual trader provided by Vissing-Jorgensen (2003) and Lo et al. (2006). Our traders have a median trading experience of 5 years, holding periods less than a day, and trade primarily using technical analysis. The average portfolio size is $\$ 198,000$.

The data set has 676 traders and contains information on almost 9000 trades. This is one of the largest panels of U.S. day traders to be analyzed in the literature. It also covers the neglected semi-professional traders identified by Goldberg and Lupercio (2003). They estimate that this group of approximately 50,000 traders makes between 25 and 50 trades per day and is responsible for nearly a third of daily trading volume during our sample period. Lastly, no other data set allows us to observe the impact of real time interaction among the chat room members.

The paper analyzes nine hypotheses. (1) Do the traders trade profitably? (2) Are their returns due to alpha? (3) Are they subject to the disposition effect? Is their stock selection influenced by (4) the representative heuristic; (5) familiarity bias; (6) the trades of other traders; (7) a tendency to avoid short positions? We then analyze two dimensions of the evolution of skills our traders appear to possess: (8) Do traders become more profitable over time? (9) Do they develop stock specific trading skills?

We find that our traders resemble, in some aspects, the more unsophisticated retail investors. They trade frequently. The most active quintile makes 26 trades per day. They exhibit the representativeness heuristic and familiarity bias, concentrating their trading in a small number of high volatility and volume NASDAQ stocks. Their stock picks are 41 percent more likely to follow the direction of a recent trade post.

For our skilled traders, many of these psychological biases do not impact their profitability. The majority of them trade profitably, after transactions costs, in each month. Contrary to the overtrading results, the traders who trade more frequently make more money, earning \$153 per trade. Adjusting for the Fama-French factors and momentum, the traders have statistically significant $\alpha \mathrm{s}$ of 0.17 percent per day. They stick with their favorite stocks throughout the trading month, independent of past returns and volatility.

In other respects, our chat room traders are quite different from the retail traders in many other studies. Our traders do not exhibit the disposition effect, holding their winners 25 percent longer than their losers. 42 percent of the traders take short positions, and their trading is more profitable short than long. Traders who trade both short and long have a 10 percent higher chance of trading profitably.

We also find evidence of learning along two dimensions: experience and stock specific skill. Trading profits from the previous year for an individual trader strongly predict trading profits in the next year; 38 percent of profits persist in the next year. Traders benefit from experience, each year in the trading room adding $\$ 189$ to their monthly trading profits. Highly concentrated portfolios have the highest profitability. Raising the trader's Herfindahl index by 0.1 raises their profit per trade by $\$ 46$.

The paper is organized as follows. The second section describes the chat room and illustrates the kind of information that we have logged. The third section describes the results of a survey of chat room participants. The fourth section focuses on profitability. We study stock selection in the fifth section. Skill evolution and survivorship is analyzed in the sixth section. A final section concludes.

\section{Description of the chat room}

Activetrader is a public Internet chat room accessible without any user fees. It is the largest of several discussion forums managed through the Financialchat.com network. With a simple piece of software known as a chat client, traders can view and post information about their trading activities that is visible to everyone else in the room. Traders register their nicknames. 
Table 1

Summary of trades and traders.

\begin{tabular}{|c|c|c|c|c|c|}
\hline & 2000 & 2001 & 2002 & 2003 & 2000-2003 \\
\hline Number of trades & 3644 & 3619 & 1133 & 571 & 8967 \\
\hline Long & 2934 & 2393 & 823 & 386 & 6536 \\
\hline Percent & 80.52 & 66.12 & 72.64 & 67.60 & 72.89 \\
\hline Short & 710 & 1226 & 310 & 185 & 2431 \\
\hline Percent & 19.48 & 33.88 & 27.36 & 32.40 & 27.11 \\
\hline Round trips & 1039 & 1210 & 238 & 113 & 2600 \\
\hline Percent & 28.51 & 33.43 & 21.01 & 19.79 & 29.00 \\
\hline Non-round trips & 2605 & 2409 & 895 & 458 & 6367 \\
\hline Percent & 71.49 & 66.57 & 78.99 & 80.21 & 71.00 \\
\hline Holding time (min) & 149.32 & 141.95 & 161.28 & 164.41 & 148.82 \\
\hline Non-round trips & 186.56 & 185.90 & 188.45 & 189.25 & 186.77 \\
\hline Round trips & 55.97 & 54.44 & 59.10 & 63.75 & 55.89 \\
\hline \multicolumn{6}{|l|}{ Traders } \\
\hline Total & 336 & 272 & 144 & 107 & \\
\hline New & 336 & 181 & 86 & 73 & 676 \\
\hline Issues traded & 470 & 406 & 256 & 196 & 919 \\
\hline NASDAQ & 421 & 368 & 203 & 154 & 786 \\
\hline NYSE & 49 & 38 & 53 & 42 & 133 \\
\hline
\end{tabular}

Notes: The table reports descriptive statistics from the authors' analysis of cross-sections from the Activetrader chat room during the period of October 2000 to July 2003.

Over short time periods, we can be sure these are unique to a specific individual. The room is monitored by about a dozen operators whose nicknames appear with an @ prefix.

The first author collected the posts from this chat room in 1-month long snapshots over a 4-year period from 2000 to 2003. There were four essentially complete trading months during this interval that form the data set for this analysis, October 2000, April 2001, April 2002, and mid-June to mid-July 2003. ${ }^{1}$ In October 2000, we have only 14 trading days of information, April 2001, a complete 22 days, April 2002, 18 days, and June-July 2003, 10 days. In total, we analyze 8967 trades.

Approximately 1300 participants post into the chat room each month during our sample. While only a small portion of those present in the room post their trades, we have compiled trading information from 676 different chat room members. In 2000, there are 336 traders, 272 in 2001, 144 in 2002, and 107 in 2003. Survival from 1 year to the next is a key focus of the analysis, but we note that each year, the majority are new traders: 66.54 percent in 2001, 59.72 percent in 2002, and 68.22 percent in 2003 (Table 1). Public access rooms like Activetrader need to be differentiated from the numerous fee-based trading rooms on the Internet. In fee-based rooms, novice traders pay to have access to the expertise of skilled traders. While there are many legitimate operations of this type, there were several well-publicized cases of abuse. A notorious example of this was a room run by a Korean-American Yun Soo Oh Park who operated under the name of "Tokyo Joe." Park was fined ${ }^{2}$ by the SEC in March 2001 for front running the picks he made in the room.

Activetrader is a decentralized organization with no master stock pickers. The role of the operators in Activetrader is primarily to filter out hyping and non-market relevant posts. Repeated violations result in traders being banned from the room. Traders are also discouraged from posting information about stocks with trading prices of less than $\$ 1.00$. The room is a cooperative venture. Traders perceive themselves to be in competition with market makers and institutional traders. While often working in isolation, they participate in a "virtual trading floor" that "simulates the ebb and flow and signals of investor sentiment." This "support group" helps traders keep track of fundamental and technical information about their stock positions. $^{3}$

\section{Survey data}

We solicited traders in the months of February and March 2004 to fill out a survey about their trading activities. We asked them questions about portfolio size, trading frequency, and entry and exit strategies. A tabulation of the survey results is in Table 2.

67 people from the Activetraders chat room participated in our survey. The average trader is a middle-aged male with $\$ 198,000$ exposed in the market.

The survey results, as well as comments received, seem to indicate that these are confident individuals who are suspicious of analysts and other insiders as demonstrated by their willingness to prefer "Internet Messages Boards" as an entry

\footnotetext{
${ }^{1}$ The logs contain 4 interruptions of more than $2 \mathrm{~h}$ when the chat client froze or when the author neglected to capture the feed. These breaks effect the status of only 6 trades and do not have any impact on the results.

${ }^{2}$ See the SEC's press release http://www.sec.gov/news/press/2001-26.txt.

3 All three quotes are from the Financialchat.com website: http://www.financialchat.com/about/.
} 
Table 2

Survey questions.

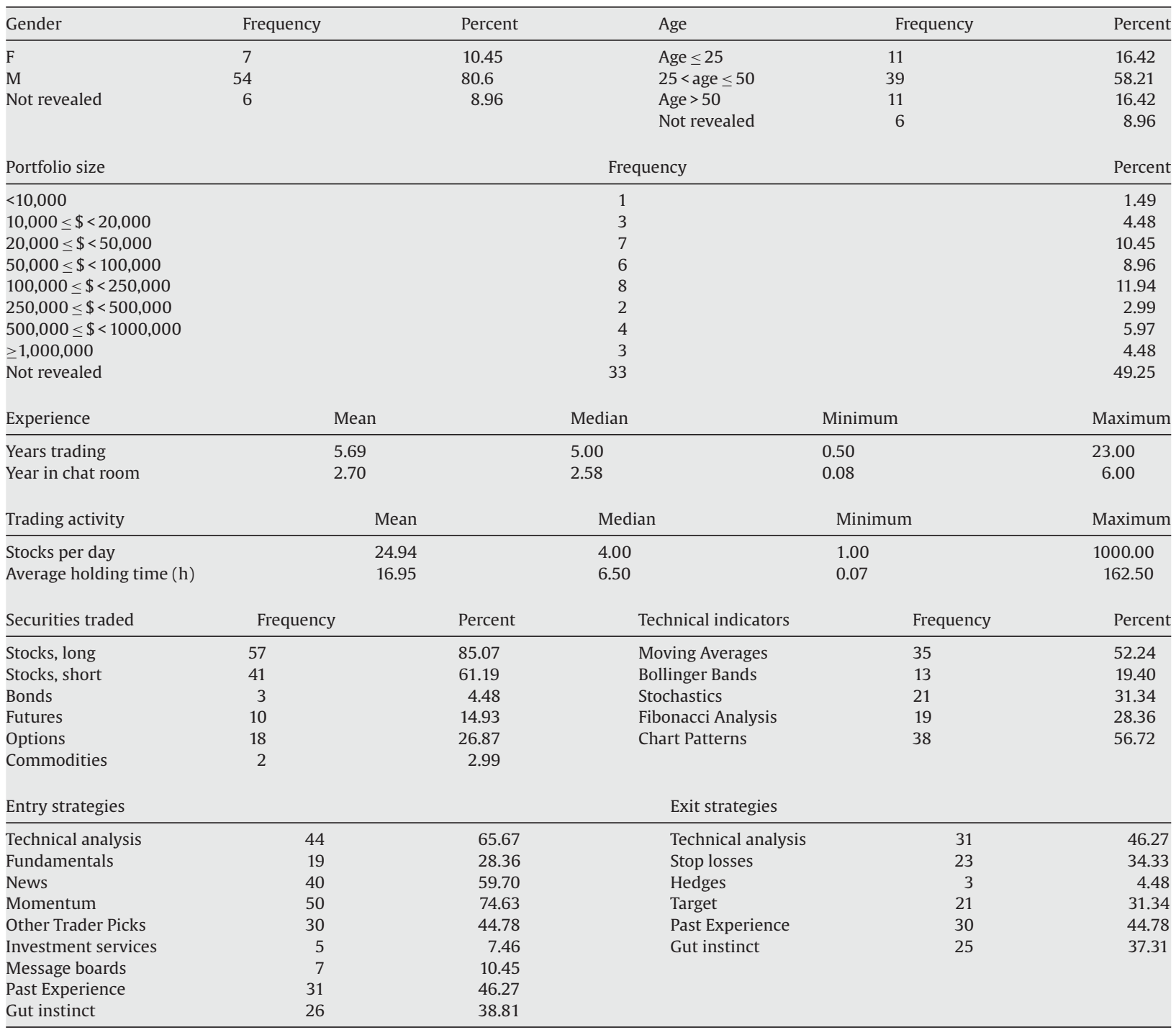

Notes: The table records a survey taken in February and March 2004 of Activetrader chat room participants.

strategy over "Investment Opinion Services". Barber and Odean (2000) have found that overconfident males tend to be poor traders.

Traders in the survey have a median of 5 years experience. Given the time period of our study, this spans the Internet bubble and the subsequent bear market. 74.64 percent of them trade 8 or fewer stocks a day, with a median of 4 . Half of them hold their trades less than $6.5 \mathrm{~h}$ (a whole trading day).

A distinctive feature of our sample is that 60.29 percent use both long and short positions. The more seasoned traders (more than 5 years) also engaged in option and futures trading, while a small minority trade commodities and bonds. It is interesting to note that the more experienced traders were the ones most likely ( 73 percent) to trade in high risk issues such as options, futures and commodities. This could indicate that as traders gain more experience, they increase risk seeking behavior in order to maximize their returns.

One of the main points of our survey was to determine how traders choose their entry point in a trade. As expected, day traders are momentum players. The survey showed that 75 percent pick a stock and its entry point based on momentum measures. Technical analysis, in its many forms, is the second most preferred method. The third most popular entry strategy (59.7 percent) was based on "News." Although "Past Experience" was the fourth most popular method with 46.27 percent, our analysis of trading activity showed that day traders tended to trade the same issues repeatedly.

39 percent of respondents selected "Gut instinct" as a reason to enter a trade. Of those who use instinct, 95 percent had traded less than 5 years. Although it is generally assumed that traders have a herd mentality, these measures did not rate 
highly in our survey. "Other Trader Picks" was only the fifth most popular response at 44.78 percent, with the other herding measures "Message Boards" and "Investment Opinion Services", getting only 10.45 and 7.46 percent support respectively.

"Stop losses" and "Target percentage" were the dominant exit strategies, used by 65.67 percent or traders. "Technical analysis" (46.27 percent) and "Past Experience" (44.78 percent) appear to help them choose the exit points. "Gut instinct" (37.31 percent) is third. Again, the less experienced traders are the most likely to cite instinct as a trading method. Our traders appear to seek short term gains rather than hedging (4.48 percent) long term positions.

Technical analysis is widely used for both entries and exits. The two most popular technical analyses tools "Chart Patterns" (56.72 percent), and "Moving Averages" (52.24 percent) are among the easiest to understand and utilize. The more complicated and mathematically demanding methods, "Stochastics", "Fibonacci Analysis", and "Bollinger Bands", are more rarely used.

The age and sex distribution of our survey is similar to the SEC (2000) day trading study and the traders in an online day trading class studied by Lo et al. (2006). Vissing-Jorgensen (2003) analyzes a large cross-section of traders in an annual survey taken by Union Bank of Switzerland from 1998 to 2002 and finds that traders with more than $\$ 100,000$ in assets are more likely to have realistic expectations about market returns and their own ability to outperform the market. They are also better diversified and trade more frequently. She concludes by asking that "it would be interesting to determine whether the ... frequent trading [of the wealthy] is rational" (p. 178). We begin our analysis of the chat room logs to answer that question.

\section{Trade identification}

Posts into the chat room are time stamped to the minute. The machine capturing the feed updated itself automatically to an atomic clock, so we know the time stamps are accurate.

We can illustrate the kind of information captured with an example from October 24, 2000 at 10:15 am EST.

$[10: 15]<$ Udaman> RCOM too heavy on the offer to bounce yet

$[10: 15]<$ HITTHEBID> scmr and cmrc

[10:15] <i4trade $>$ will accumulate RCOM if it drops further

$[10: 15]<$ WHP $>$ XLNX green

[10:15] <Matrix > YHOO broke yesterday's highs

[10:16] < gladiator> scmr nice

[10:16] $<$ ferrari $>$ MRCH thru 5 here

[10:16] $<$ HCG $>$ CMRC oh my this thing runs hard

[10:16] Matrix buys some PCLN on YHOO's heat

[10:16] Guest05067 is now known as RB

[10:16] $<$ PACKER $>$ aol boooming

[10:16] < BigCheez> RCOM downgraded this am at 7 (they loved it at 100 though lol)

[10:16] $<$ whatgoesup $>$ ADSX up up

[10:16] < Unforgiven> DCLK is back!

[10:16] < REact> Whew! sure glad I dumped my DCLK this am @ $13.5+1 / 8$ *\#\$*

[10:16] < ferrari> MRCH nailed it

$[10: 16]<$ thewoman $>$ MRCH gonna go a bit here

[10:16] HCG sells $1 / 2$ CMRC +3/4

The posts primarily contain information about technical analysis. Notice the observations by Udaman about Register.COM (RCOM) and Matrix on Yahoo (YHOO) clearing a particular resistance level. There are also posts about fundamentals. BigCheez is reporting on an analyst report on RCOM. In general, these fundamental posts are restricted to news events like upgrades and earnings announcements. There is very little debate about the merits of a company's products or earnings, as in the bulletin board information studies by Antweiler and Frank (2004).

We filter out this information to isolate the trade posts. There are two in this group, the purchase of Priceline.com by Matrix and the sale of Commerce One Inc. (CMRC) by HCG, both at 10:16. Neither trader posts an entry or exit price or a trade size. We do not rely on posted prices from traders, when they are available, unless we can match them to quote data. Since we cannot verify the trade size, we make several assumptions in the return analysis.

Traders use a wide variety of slang for their trades. We used various forms of the keywords, including their abbreviations and misspelled variants, to indicate buying activity: Accumulate; Add; Back; Buy; Cover; Enter; Get; Grab; In; Into; Load; Long; Nibble; Nip; Pick; Poke; Reload; Take; and Try. Keywords for selling were: Dump; Out; Scalp; Sell; Short; Stop; and Purge.

We cannot match open and closing trades for about 70 percent of the posts. We assume that all open positions whether long or short are closed at the end of the day. We do not consider after hours trades. 
Table 3

Trading profits.

\begin{tabular}{|c|c|c|c|c|c|}
\hline & 2000 & 2001 & 2002 & 2003 & 2000-2003 \\
\hline \multicolumn{6}{|l|}{ All trades } \\
\hline 1 share profit & 418.23 & 550.74 & 96.11 & 119.95 & $1,185.03$ \\
\hline Profit (A) & $349,578.10$ & $479,332.90$ & $73,532.00$ & $111,130.00$ & $1,013,572.99$ \\
\hline Profit (B) & $234,630.17$ & $688,266.90$ & $-54,975.49$ & $203,321.95$ & $1,071,243.53$ \\
\hline Profit per trade & 135.06 & 183.31 & 44.88 & 245.67 & 152.66 \\
\hline Profitable traders (A) (percent) & 52.82 & 54.12 & 51.03 & 71.03 & 54.79 \\
\hline Profitable traders (B) (percent) & 47.48 & 50.54 & 41.38 & 57.01 & 48.67 \\
\hline \multicolumn{6}{|l|}{ Long trades } \\
\hline 1 share profit & 343.13 & 403.00 & 48.97 & 92.60 & 887.70 \\
\hline Profit (A) & $284,289.30$ & $355,254.99$ & $32,332.00$ & $84,760.00$ & $756,636.29$ \\
\hline Profit (B) & $202,613.34$ & $660,521.32$ & $-41,043.78$ & $148,039.78$ & $970,130.65$ \\
\hline Profit per trade & 45.22 & 204.47 & 2.23 & 309.15 & 110.87 \\
\hline Profitable traders (A) (percent) & 50.80 & 54.78 & 48.46 & 70.71 & 53.97 \\
\hline Profitable traders (B) (percent) & 45.66 & 50.00 & 40.00 & 57.58 & 47.59 \\
\hline \multicolumn{6}{|l|}{ Short trades } \\
\hline 1 share profit & 79.61 & 148.60 & 47.38 & 30.15 & 305.74 \\
\hline Profit (A) & $65,288.80$ & $124,077.90$ & $41,200.00$ & $26,370.00$ & $256,936.70$ \\
\hline Profit (B) & $32,016.84$ & $27,745.56$ & $-13,931.71$ & $55,282.18$ & $101,112.87$ \\
\hline Profit per trade & 364.27 & 141.63 & 146.96 & 52.70 & 210.84 \\
\hline Profitable traders (A) (percent) & 59.48 & 53.54 & 54.69 & 57.50 & 56.07 \\
\hline Profitable traders (B) (percent) & 51.72 & 48.82 & 45.31 & 42.50 & 48.27 \\
\hline
\end{tabular}

Notes: The table reports estimates of trader profits under three assumptions. 1 share profit is the aggregate difference between entry and exit prices. Assumption A is a 1000 share lot size with a 20 commission. B assumes a 25,000 position, with a 0.005 per share commission, and 0.5 percent slippage. The profit per trade is based on a regression of profits for trader $j$ on the number of trades and a constant term.

\section{Profit and return analysis}

There are three major concerns that must be addressed in computing the profitability of trading in the chat room. First, we do not observe position sizes. These are rarely reported and are probably unreliable. We will make two assumptions: (A) 1000 share lot size ${ }^{4}$; (B) 25,000 per trade. ${ }^{5}$ Second, we also do not observe actual trading prices, but fortunately, these can be matched against quote data. We compare the price posted by the trader to the high and low bid price during the minute the trade is posted. If the price posted falls in this range, we use the trader's posted price. If it does not, we use the opening bid price for that minute. We find that 5.32 percent of trade reports use unreliable prices that deviate more than 1 percent from the 1-min quote range. The third concern relates to trades in which we observe only entries or exits. We complete these trades using the close or open for the day. This section ends with a robustness check of these assumptions.

\subsection{Profits}

To compute profit and losses for each trader, we add transaction costs to our position size assumptions A and B. For A, we assume a $\$ 20$ commission. $^{6}$ This is a $\$ 0.02$ per share commission on the 1000 share round trip. For position size $B$, we assume a $\$ 0.005$ per share commission and a 50 basis point slippage. These reflect the lower commissions typically paid on larger lot sizes and some market impact on the larger trades. ${ }^{7}$ We find that none of the position or transaction costs assumptions has a qualitative impact on our profit estimates.

We examine profits for all trades for the 4 months in Table 3. We first measure the difference between selling and buying prices. The second measure A uses the low cost estimate with flat commissions. The second measure B has higher transactions costs but sometimes benefits from the larger lot sizes.

Before transactions costs, the traders are profitable in the aggregate in all 4 years. Under A, the traders earn an aggregate profit of \$1,013,572.99. Nearly half of the money is earned in the April 2001 trading month. That was a good month for the market, with the NASDAQ 100 index was up more than 15 percent. The traders earn money in bad months too though; the second most profitable month is 2000 with $\$ 349,578.10$ when the Nasdaq 100 index was down almost 10 percent.

\footnotetext{
${ }^{4}$ The majority of traders in the North American Securities Administrator Association (1999) study used 1000 share lots. The lot size is also consistent with anecdotes in the trade press.

$5 \$ 25,000$ is the minimum needed to receive 4 to 1 intraday leverage on a day trading margin account. This averages out to a 1000 share lot size for the typical \$25 stock, but allows for larger positions on lower priced securities. The North American Securities Administrators Association (1999) report also shows that day traders routinely risked $10-15$ percent of their capital on trades, which given our survey average net worth of $\$ 198,000$, is between $\$ 20$ and 30,000 .

6 The SEC (2000) day trading study surveyed 22 day trading brokers and found a commission range between 15 and 25 per share.

7 Interactive Brokers, cited by Barron's as the best online broker for active traders, charges this commission for trades of more than 500 shares. The slippage assumes paying slightly less than the average effective spread in Van Ness et al. (2005) on entering and exiting the trade.
} 
Table 4

Risk adjusted returns.

\begin{tabular}{|c|c|c|c|c|c|c|}
\hline Year & $\alpha$ & Mkt- $R_{f}$ & SMB & HML & Momentum & $\bar{R}^{2}$ \\
\hline 2000 & $\begin{array}{l}0.444 \\
(1.61)\end{array}$ & $\begin{array}{l}0.648 \\
(1.24)\end{array}$ & $\begin{array}{c}1.770 \\
(1.67)\end{array}$ & $\begin{array}{l}0.549 \\
(0.69)\end{array}$ & $\begin{array}{l}0.236 \\
(1.55)\end{array}$ & 0.289 \\
\hline 2001 & $\begin{array}{l}0.221 \\
(2.87)\end{array}$ & $\begin{array}{l}-0.036 \\
(0.36)\end{array}$ & $\begin{array}{l}-0.027 \\
(0.20)\end{array}$ & $\begin{array}{l}-0.004 \\
(0.02)\end{array}$ & $\begin{array}{l}-0.024 \\
(0.78)\end{array}$ & -0.194 \\
\hline 2002 & $\begin{array}{l}0.225 \\
(4.24)\end{array}$ & $\begin{array}{l}-0.005 \\
(0.13)\end{array}$ & $\begin{array}{l}-0.377 \\
(3.97)\end{array}$ & $\begin{array}{l}-0.556 \\
(4.87)\end{array}$ & $\begin{array}{l}0.031 \\
(1.10)\end{array}$ & 0.684 \\
\hline 2003 & $\begin{array}{l}0.003 \\
(0.03)\end{array}$ & $\begin{array}{l}0.113 \\
(1.44)\end{array}$ & $\begin{array}{l}0.206 \\
(1.79)\end{array}$ & $\begin{array}{l}-0.043 \\
(0.16)\end{array}$ & $\begin{array}{l}-0.030 \\
(1.09)\end{array}$ & 0.147 \\
\hline 2000-2003 & $\begin{array}{l}0.170 \\
(2.25)\end{array}$ & $\begin{array}{l}0.003 \\
(0.04)\end{array}$ & $\begin{array}{l}0.075 \\
(0.50)\end{array}$ & $\begin{array}{l}-0.246 \\
(1.76)\end{array}$ & $\begin{array}{l}0.049 \\
(1.55)\end{array}$ & 0.081 \\
\hline
\end{tabular}

Notes: The table provides estimates of the influence of market factors on the chat room's daily returns. The first factor is the market return less the 1-month Treasury bill rate. The second factor SMB adjusts for market capitalization. The third factor HML adjusts for value versus growth. These three factors were obtained from Ken French's website: http://mba.tuck.dartmouth.edu/pages/faculty/ken.french/data_library.html. The momentum factor is constructed by the authors using the Carhart (1997) methodology.

Under assumption B, trading profits are negative in the month of April 2002, $-\$ 54,975.49$. The larger lot sizes though provide greater profits in 2001 and 2003. Aggregate profits are actually $\$ 57,670.54$ larger under B at $\$ 1,071,243.53$ than under A.

More than 50 percent of traders are profitable in every month under A, with 71 percent profitable in the market of June-July 2003. At least 40 percent of the traders are profitable under B, with a low of 41.38 percent in April 2002 and a high of 57.01 percent in 2003. These are much higher ratios of profitable traders than those found in other studies of retail investors or the day traders studied by Barber et al. (2009) or Jordan and Diltz (2003). This is why we feel comfortable regarding these semi-professional and professional traders as experts.

To determine the marginal benefit of additional trading, we regress the profits of each trader under assumption A on the number of trades they make during the month. We find a strong positive incremental profit of $\$ 152.66$ per trade in the pooled sample. In the month of June-July 2003, with a smaller number of surviving traders as the bear market ends, each trade earns an incremental profit of \$245.67. The experts in our chat room are "Activetraders" for a good reason; trading, for them, is a profitable activity.

\subsection{Adjusted returns}

Our return analysis examines the risk return trade-off of a representative trader with the survey average $\$ 198,000$ portfolio. We assume that the funds the trader does not use in the chat room earn the risk free rate of return.

We measure excess returns as daily portfolio returns $R_{p, t}$ less the risk free rate, $R_{f}$. We use the 1 -month Treasury bill rate compiled by Ibbotson associates and collected by Fama and French as the risk free rate. The daily excess returns in the chat room are positive in every trading month, 0.200 percent in 2000, 0.228 percent in 2001, 0.059 percent in 2002, and 0.149 percent in 2003. For the 64 trading days studied, daily returns average 0.166 percent.

We also adjust the returns for the three Fama and French (1993) factors and a factor for momentum. The first factor is the value weighted return on all NYSE, NASDAQ and AMEX stocks less the risk free rate. This is the standard CAPM factor. The second factor SMB adjusts for market capitalization. It places $1 / 3$ weights on the difference between three small portfolios and three big portfolios consisting of value, neutral and growth stocks. The third factor HML adjusts for value versus growth. It is the average difference of two value and two growth portfolios.

The data for the first three factors are from the daily return series on Ken French's website. ${ }^{8}$ We constructed the fourth factor using the methodology in Carhart (1997) and Barber et al. (2006). It consists of a portfolio of stocks with the highest and lowest 30 percent of returns in the preceding trading month. The momentum factor is the daily return difference between an equal weighted portfolio of the high and low return stocks.

These four factors explain, except for 2001, between 15 and 68 percent of excess returns of the chat room traders in Table 4 . The CAPM and momentum factors are never statistically significant. $\alpha$ is significant in 2001 and 2002 and the pooled sample for 2000-2003. Based on the full 64 day sample, we conclude that an $\alpha$ of 0.170 percent is convincing evidence of trader expertise. The insignificance of the momentum factor also suggests the traders are doing something more sophisticated than chasing high return stocks.

\footnotetext{
${ }^{8}$ http://mba.tuck.dartmouth.edu/pages/faculty/ken.french/Data_Library/f-f_factors.html.
} 
Table 5

Profit shares by activity level.

\begin{tabular}{lcr}
\hline Group & Trades (percent) & Profits (percent) \\
\hline All trades 2000-2003 & & 83.33 \\
1st quintile & 9.31 & 90.34 \\
2nd quintile & 3.96 & 0.97 \\
3rd quintile & 1.93 & 6.64 \\
4th quintile & 1.47 & 0.93 \\
5th quintile & 43.95 & 1.12 \\
Top ten & & 43.07 \\
\hline
\end{tabular}

Notes: The table provides percentages of trades and profits sorted by trading activity level. The percentage is the share of the 8967 trades posted into the room. Profits are computed using Assumption A and total $\$ 1,071,243.53$. Top ten refers to the 10 most active traders in the sample.

\subsection{Profits of most active traders}

Trading profits are highly concentrated in the sample. The top ten traders post 43.95 percent of the trades and earn, using Assumption A, 43.07 percent of the profits. Trading activity and profits by quintile are reported in Table 5 .

All the quintiles earn trading profits, and profits are strongly correlated with trading activity. The second quintile, with less than 1 percent of the profit and nearly 10 percent of the trades, is an outlier.

These results stand in contrast to the retail traders in Barber and Odean (2000). In their sample, the top activity quintile had the worst underperformance. In this sample of semi-professional traders, active trading seems to be a money-making pursuit.

\subsection{Reporting bias}

Traders more often post their profits on good trades, and this reporting bias could potentially influence our results. Round trips are profitable 67.35 percent of the time. The trades we open or close at the beginning or end of the day are profitable only 50.48 percent of the time.

Consider first the effects of using the opening trade price as an entry when we observe the exit. One concern might be that traders would post trades in stocks that had moved substantially during the day, a form of window dressing. This does not appear to be the case with our data though. The trades with no entry post have a 2.74 percent lower profit per trade than the rest of the sample.

For the trades with no exit, the concern is that traders are reluctant to report losses. To check the impact of using the close as an exit price, we randomly selected 250 trades and chose a random entry price between the daily high and low for those trades. In this sub-sample, 63.67 percent of the trades are profitable. This is insignificantly different than the mean for the entire sample. This implies that, if anything, the incomplete exit trades are biasing down the chat room profits.

A related concern is that only skilled traders are posting their trades, and this effect grows as poor traders leave the chat room. The skills that enhance profitability and the learning from experience are quantified in the next two sections.

\section{Effect of holding period on profits}

Activetrader is primarily populated by day traders. Table 1 shows that they have very short holding times on average. The average trade duration is $55.11 \mathrm{~min}$ for trades where we see both entries and exits. We call these trades round trips. These represent only about 30 percent of trades. For the trades we close out, the average duration is $186.77 \mathrm{~min}$. We now assess the effects of these trading decisions on profits and returns.

To calculate the disposition effect, we calculate the length of the holding period for winners and losers in the entire chat room's portfolio. We used only the round-trip trades where we have entry and exit time stamps.

We find that our traders realize their losses quickly and hold their winners longer. The average holding period for losing trades was $47.87 \mathrm{~min}$. Winners were held on average 25 percent longer or $60.23 \mathrm{~min}$. These results contrast with several others in the literature: Jordan and Diltz (2004), where 62 percent of traders held their losers longer; Lehenkari and Perttunen(2004), who found a one-sided effect of losses on the propensity to sell; and Garvey and Murphy (2004), where the disposition effect lowered the returns of profitable professionals.

Shefrin and Statman (1985) pointed out that professional traders employ pre-commitment mechanisms such as stop losses and target percentages to control their resistance to realizing losses. Our survey data and trade postings from Activetrader corroborate the use of these techniques. Dhar and Zhu (2006) found that wealthier and well-educated traders could mitigate the disposition effect. The chat room traders do not allow the disposition effect to erode their profits.

\section{Stock selection}

This section examines stock selection by the chat room as a whole. Some descriptive statistics of the cross-section, sorted by trading frequency, are in Table 6. 
Table 6

Cross-section of stocks.

\begin{tabular}{llll}
\hline Group & Mkt. cap. & Volume & Beta \\
\hline All trades 2000-2003 & & & 7.42 \\
1st quintile & $15,475.11$ & 3.09 & 2.03 \\
2nd quintile & $7,277.29$ & 2.48 & 1.47 \\
3rd quintile & $4,119.53$ & 1.30 & 1.21 \\
4th quintile & $3,972.44$ & 0.89 & 0.95 \\
5th quintile & $5,060.92$ & 3.02 & 1.07 \\
Avg. & $7,132.26$ & 1.34 \\
\hline
\end{tabular}

Notes: The table reports characteristics of the most actively traded stocks, sorted by quintile. Stock market capitalization is in millions of $\$$, average trading volume is in billions for the prior month, and $\beta$ is measured as the prior 50-day covariance with the S\&P 500 index.

Our traders trade large market capitalization stocks, with high trading volumes, and high betas. Our objective in this section is to understand why, on a particular day, traders pick a particular stock. We test four hypotheses on individual trading frequency. Do traders focus on attention grabbing stocks? What factors drive these choices? Are their trades influenced within the day by other traders? Do they tend to avoid short positions like most retail traders?

Then we try to examine whether traders focus on a relatively small number of stocks. We compute Herfindahl indexes that we will later use in our return analysis. We conclude with a brief examination of short selling.

\subsection{Daily trading frequency}

Let $n_{k, t}$ denote the number of trades in stock $k$ on day $t$. Define $n_{k, t}^{b}$ and $n_{k, t}^{a}$ analogously for the long and short trades. $N_{t}=\sum_{K} n_{k, t}^{b}+n_{k, t}^{a}$ is the total number of trades, where $K$ denotes the universe of securities. The totals for long and short trades are $N_{t}^{b}=\sum_{K} n_{k, t}^{b}$ and $N_{t}^{a}=\sum_{K} n_{k, t}^{a}$.

Denote the daily trading frequency in stock $k$,

$$
p_{k, t}=\frac{n_{k, t}}{N_{t}} .
$$

Define $p_{k, t}^{b}$ and $p_{k, t}^{a}$ similarly for long and short trades.

Barber and Odean (2008) have examined the question of stock selection among individual investors and find in a large sample of retail traders and investors that traders tend to buy attention grabbing stocks. They measure this in three ways: abnormal trading volume, previous day's returns, and the square of the previous day's returns. Using daily data from CRSP, we measured abnormal volume $A V_{k, t-1}$ as the percentage difference from the 50-day Moving Average. The return series is constructed from daily closing prices. A positive effect from past returns is a prediction of the representativeness heuristic. The squared return is a proxy ${ }^{9}$ for volatility.

$$
p_{k, t}=b_{0}+b_{1} p_{k, t-1}+b_{2} A V_{k, t-1}+b_{3} R_{k, t-j}+b_{4} R_{k, t-1}^{2} .
$$

This regression adds the lagged trading frequency modeled by Barber et al. (2006). We estimate this equation, pooled and by month, for all trades, buys and short sells separately. Results are in Table 7.

For the sample as a whole, for all trades, two regressors are significant, the lagged trading frequency and the abnormal volume. It is the lagged frequency, however, that predominates. It has a much stronger $t$-ratio, and it enters significantly in all the sub-samples. Abnormal volume only enters significantly in the grouped 4-year sample for all trades. A ten million share increase in abnormal volume would raise the overall trading frequency by only 0.03 percent. The four variables explain about 11.5 percent of the trade frequency. In the 2002 sub-sample, the $R^{2}$ is the highest at $22.4 \%$.

Long and short trades are driven by the previous day's trading frequency. For long trades, the lagged trading frequency is significant in each sub-sample. Abnormal volume is significant in the overall sample, and lagged returns matter in 2000 and 2002. Short trade frequencies have less persistence than long ones. $b_{1}$ is significant on the short trades only in 2003 , and in the grouped 4-year sample. The model also fits the long trades slightly better than the short ones.

Our interpretation of the lagged frequency variable is different than Barber et al. (2006). Traders do have a familiarity bias, but we attribute this to stock specific trading skills. We find below, in our examination of profits, that traders who stick with a few familiar stocks make more money.

\subsection{Influences from other traders}

One of the reasons to be in a chat room is to receive input from other traders. We observe a reasonably large group of people who, through technology, share a common information set. We examine in this section

\footnotetext{
${ }^{9}$ We also looked at the intra-daily range $\left|p_{t}^{\text {High }}-p_{t}^{\text {Low }}\right|$ and found no significant influence.
} 
Table 7

Daily stock selection regressions.

\begin{tabular}{|c|c|c|c|c|c|c|}
\hline Sample & Constant & $p_{k, t-1}$ & $A V_{k, t-1}$ & $R_{k, t-1}$ & $R_{k, t-1}^{2}$ & $\bar{R}^{2}$ \\
\hline \multicolumn{7}{|l|}{ All trades } \\
\hline 2000 & $\begin{array}{l}2.140 \\
(13.91)\end{array}$ & $\begin{array}{l}0.149 \\
(2.78)\end{array}$ & $\begin{array}{l}0.004 \\
(1.45)\end{array}$ & $\begin{array}{l}-0.030 \\
-(2.21)\end{array}$ & $\begin{array}{l}0.000 \\
-(1.15)\end{array}$ & 0.057 \\
\hline 2001 & $\begin{array}{l}2.104 \\
(20.20)\end{array}$ & $\begin{array}{l}0.309 \\
(8.19)\end{array}$ & $\begin{array}{l}-0.001 \\
-(0.44)\end{array}$ & $\begin{array}{l}-0.001 \\
-(0.14)\end{array}$ & $\begin{array}{l}0.000 \\
-(0.55)\end{array}$ & 0.114 \\
\hline 2002 & $\begin{array}{l}2.267 \\
(15.12)\end{array}$ & $\begin{array}{l}0.485 \\
(9.94)\end{array}$ & $\begin{array}{l}0.001 \\
(0.57)\end{array}$ & $\begin{array}{l}-0.059 \\
-(2.89)\end{array}$ & $\begin{array}{l}0.000 \\
-(0.36)\end{array}$ & 0.224 \\
\hline 2003 & $\begin{array}{l}3.362 \\
(12.38)\end{array}$ & $\begin{array}{l}0.506 \\
(5.69)\end{array}$ & $\begin{array}{l}0.005 \\
(1.69)\end{array}$ & $\begin{array}{l}-0.009 \\
-(0.21)\end{array}$ & $\begin{array}{l}0.000 \\
-(0.35)\end{array}$ & 0.138 \\
\hline 2000-2003 & $\begin{array}{l}2.351 \\
(29.62)\end{array}$ & $\begin{array}{l}0.353 \\
(13.03)\end{array}$ & $\begin{array}{l}0.003 \\
(2.31)\end{array}$ & $\begin{array}{l}-0.010 \\
-(1.52)\end{array}$ & $\begin{array}{l}0.000 \\
-(1.32)\end{array}$ & 0.115 \\
\hline \multicolumn{7}{|l|}{ Long trades } \\
\hline 2000 & $\begin{array}{l}2.004 \\
(12.53)\end{array}$ & $\begin{array}{l}0.151 \\
(2.36)\end{array}$ & $\begin{array}{l}0.004 \\
(1.49)\end{array}$ & $\begin{array}{l}-0.028 \\
-(1.97)\end{array}$ & $\begin{array}{l}0.000 \\
-(1.03)\end{array}$ & 0.060 \\
\hline 2001 & $\begin{array}{l}1.979 \\
(17.57)\end{array}$ & $\begin{array}{l}0.203 \\
(4.16)\end{array}$ & $\begin{array}{l}-0.002 \\
-(0.89)\end{array}$ & $\begin{array}{l}0.001 \\
(0.12)\end{array}$ & $\begin{array}{l}0.000 \\
-(0.11)\end{array}$ & 0.046 \\
\hline 2002 & $\begin{array}{l}1.951 \\
(13.41)\end{array}$ & $\begin{array}{l}0.497 \\
(8.76)\end{array}$ & $\begin{array}{l}0.000 \\
-(0.03)\end{array}$ & $\begin{array}{l}-0.039 \\
-(1.97)\end{array}$ & $\begin{array}{l}0.001 \\
(0.67)\end{array}$ & 0.226 \\
\hline 2003 & $\begin{array}{l}3.178 \\
(13.45)\end{array}$ & $\begin{array}{l}0.237 \\
(1.58)\end{array}$ & $\begin{array}{l}0.004 \\
(1.51)\end{array}$ & $\begin{array}{l}-0.023 \\
-(0.65)\end{array}$ & $\begin{array}{l}0.000 \\
-(0.14)\end{array}$ & 0.028 \\
\hline 2000-2003 & $\begin{array}{l}2.196 \\
(28.22)\end{array}$ & $\begin{array}{l}0.278 \\
(8.30)\end{array}$ & $\begin{array}{l}0.002 \\
(1.97)\end{array}$ & $\begin{array}{l}-0.010 \\
-(1.65)\end{array}$ & $\begin{array}{l}0.000 \\
-(1.28)\end{array}$ & 0.070 \\
\hline \multicolumn{7}{|l|}{ Short trades } \\
\hline 2000 & $\begin{array}{l}1.834 \\
(12.35)\end{array}$ & $\begin{array}{l}-0.034 \\
-(0.31)\end{array}$ & $\begin{array}{l}0.002 \\
(0.83)\end{array}$ & $\begin{array}{l}-0.020 \\
-(1.22)\end{array}$ & $\begin{array}{l}-0.001 \\
-(1.00)\end{array}$ & 0.068 \\
\hline 2001 & $\begin{array}{l}2.084 \\
(12.71)\end{array}$ & $\begin{array}{l}0.077 \\
(1.06)\end{array}$ & $\begin{array}{l}0.001 \\
(0.27)\end{array}$ & $\begin{array}{l}-0.012 \\
-(0.94)\end{array}$ & $\begin{array}{l}0.001 \\
(0.80)\end{array}$ & 0.014 \\
\hline 2002 & $\begin{array}{l}2.583 \\
(10.48)\end{array}$ & $\begin{array}{l}0.055 \\
(0.47)\end{array}$ & $\begin{array}{l}0.005 \\
(1.20)\end{array}$ & $\begin{array}{l}-0.005 \\
-(0.14)\end{array}$ & $\begin{array}{l}0.000 \\
-(0.02)\end{array}$ & 0.029 \\
\hline 2003 & $\begin{array}{l}2.877 \\
(5.80)\end{array}$ & $\begin{array}{l}0.530 \\
(3.59)\end{array}$ & $\begin{array}{l}0.004 \\
(0.66)\end{array}$ & $\begin{array}{l}0.001 \\
(0.01)\end{array}$ & $\begin{array}{l}0.000 \\
-(0.18)\end{array}$ & 0.154 \\
\hline 2000-2003 & $\begin{array}{l}2.251 \\
(17.18)\end{array}$ & $\begin{array}{l}0.266 \\
(4.81)\end{array}$ & $\begin{array}{l}0.002 \\
(1.03)\end{array}$ & $\begin{array}{l}-0.018 \\
-(1.24)\end{array}$ & $\begin{array}{l}0.000 \\
(0.31)\end{array}$ & 0.057 \\
\hline
\end{tabular}

Notes: The table reports estimates of the model (2) for $p_{k, t}$, the probability of trading stock $k$ during the trading day $t$. The explanatory variables are the lagged daily trade frequency, abnormal volume, returns, and squared returns. $t$-ratios are in parentheses.

whether the decision by a chat room trader to buy (sell) or cover (short) is impacted by the trade posts in the room.

Let $x_{k, t}$ be a signed trade in stock $k$, with +1 indicating a buy and -1 a sell. We control for the intraday trend in the stock by measuring the deviation from the daily average for this variable, $\bar{x}_{k, t}$.

We define a following trade as a decision by trader $j$ to buy/cover or sell/short within 15 min after a trader other than $j$ posts a trade. Denote this as $x_{-j, k, t}$ and sign it according to trade direction, or give it a value of zero if there is no following trade.

To test the influence of recent posts from other traders, we estimate for the full sample,

$$
x_{k, t}-\bar{x}_{k, t}=\underset{(5.04)}{-0.039}+\underset{(28.29)}{0.407 x_{-j, t}}+\underset{(12.54)}{0.137 x_{k, t-1}}
$$

We control for the expected positive autocorrelation in buy or sell orders by including a lag in the dependent variable.

The estimates show a strong influence from other traders, with a buy (sell) order 40.7 percent more likely to be of the same sign if there has been a recent post.

\subsection{Short selling}

Traders in the Activetrader chat room short more often than do retail traders. As we noted in the introduction, short selling is used by less than 0.30 percent of the retail traders in Barber and Odean (2008). 
In Table 1, we see that our active traders short very often, more than 27 percent of the time over the 4 months. In the peak month, April 2001, 33.88 percent of the trades are shorts. 41.58 percent of traders make at least one short sale in the 4-year sample.

Our traders make money trading both long and short. When we break apart profits short versus long, we find that 74.7 percent of profits are made trading long and 25.3 percent short. Trades are equally likely to be profitable long versus short, 53.97 percent long compared to 56.07 percent short. The marginal profit per trade is substantially higher on the short side than the long, $\$ 210.84$ per trade short versus $\$ 110.87$ long in the pooled sample. Short traders are also more skillful overall. Over the 4 years, 51.55 percent of traders who never short are profitable under assumption A, compared with 62.21 for traders who trade both short and long.

\subsection{Trade concentration}

We first measure concentration by looking at the proportion of trades in the most active securities. We then report Herfindahl indexes for the room and the most active individual traders.

\subsubsection{Frequently traded stocks in the chat room}

The most frequent stocks selected are listed by symbol in Table 8 .

In 2000 and 2001, we see Internet related companies among the top ten in both years. JDS Uniphase (JDSU) is the most active in 2000 with 157 trades and the second most active in 2001 with 127. The rest of the top 10 changes between 2000 and 2001. In 2001, an exchange traded fund that tracks the NASDAQ 100 index, QQQ is among the ten most active. It becomes the most actively traded stock in 2002 and 2003.

In 2002, Internet and technology names continue to dominate, but the only carryover from 2001 is VeriSign, Inc. (VRSN). The same is true comparing 2003 and 2002. Only the QQQ is in the top ten in both years. In 2003, there is more activity in non-NASDAQ issues. Loral Corporation, LOR, and AMR Corporation, AMR, are the only NYSE issues in the top ten in any of the 4 months. They are third and fifth in 2003.

A rank correlation analysis reveals little persistence in the top 25 stocks from year to year. The correlation between 2001 and 2000 is 0.1082 , between 2002 and 2001, -0.0507 , and between 2003 and 2002, -0.2242;

While the individual securities traded show considerable variation between sample months, trading activity does remain confined in a small number of issues. We measure this formally using the Herfindahl index

$$
H_{t}=\sum_{K}^{\stackrel{2}{p}}
$$

If trades were distributed uniformly, the Herfindahl index would equal $1 / K$. If all trading was in a single stock, then the Herfindahl would equal 1.0. We will take as the null hypothesis that the Herfindahl index of trading activity in the room

$$
H_{\omega, t}=\sum_{K}^{\stackrel{2}{\omega}, t}
$$

where

$$
\omega_{k, t}=\frac{V_{k, t}}{\sum_{K} V_{k, t}},
$$

is proportional to $V_{k, t}$, the trading volume in the market as a whole.

We compare the two Herfindahl indexes in Table 9, using an F-test for the variance ratio,

$$
\frac{K H_{t}-1}{K H_{\omega, t}-1} \text {. }
$$

In Table 9, we find that none of the Herfindahl numbers exceed the market's measure. The room as a whole is significantly less concentrated than the market.

\subsubsection{Herfindahl indexes for traders}

We now examine whether individual traders are concentrated even if the room is not. Define the trading frequency of trader $j$ in the $k$ th security on day $t$,

$$
p_{j, k, t}=\frac{n_{j, k, t}}{N_{j, t}} .
$$

where $n_{j, k, t}$ is the number of trades and $N_{j, t}=\sum_{K} n_{j, k, t}^{b}+n_{j, k, t}^{a}$. Define a Herfindahl index for trader $j$

$$
H_{j, t}=\sum_{K} \stackrel{2}{p}
$$


G Model

JEBO-2314; No. of Pages 16

Table 8

Stock trading concentration by issue 2000-2003.

\begin{tabular}{|c|c|c|c|c|c|c|c|}
\hline \multicolumn{4}{|l|}{2000} & \multicolumn{4}{|l|}{2001} \\
\hline Stock & \# & Percent & Cum. percent & Stock & $\#$ & Percent & Cum. percent \\
\hline JDSU & 157 & 4.31 & 4.31 & JNPR & 145 & 4.01 & 4.01 \\
\hline INTC & 121 & 3.32 & 7.63 & JDSU & 127 & 3.51 & 7.52 \\
\hline CSCO & 105 & 2.88 & 10.51 & VRSN & 127 & 3.51 & 11.03 \\
\hline AMCC & 101 & 2.77 & 13.28 & QQQ & 115 & 3.18 & 14.20 \\
\hline YHOO & 101 & 2.77 & 16.05 & ARBA & 81 & 2.24 & 16.44 \\
\hline SCMR & 90 & 2.47 & 18.52 & SUNW & 78 & 2.16 & 18.60 \\
\hline ISLD & 78 & 2.14 & 20.66 & CIEN & 65 & 1.80 & 20.39 \\
\hline ICGE & 65 & 1.78 & 22.45 & RFMD & 61 & 1.69 & 22.08 \\
\hline COVD & 62 & 1.70 & 24.15 & NUFO & 57 & 1.58 & 23.65 \\
\hline QQQ & 58 & 1.59 & 25.74 & CSCO & 56 & 1.55 & 25.20 \\
\hline PCLN & 52 & 1.43 & 27.17 & MUSE & 53 & 1.46 & 26.66 \\
\hline SDLI & 49 & 1.34 & 28.51 & INKT & 50 & 1.38 & 28.05 \\
\hline CMGI & 47 & 1.29 & 29.80 & PPRO & 50 & 1.38 & 29.43 \\
\hline JNPR & 41 & 1.13 & 30.93 & AMCC & 47 & 1.30 & 30.73 \\
\hline CIEN & 40 & 1.10 & 32.03 & СНКР & 47 & 1.30 & 32.03 \\
\hline PMCS & 39 & 1.07 & 33.10 & BRCM & 46 & 1.27 & 33.30 \\
\hline RMBS & 39 & 1.07 & 34.17 & SONS & 45 & 1.24 & 34.54 \\
\hline TLXS & 38 & 1.04 & 35.21 & TERN & 44 & 1.22 & 35.76 \\
\hline AFCI & 37 & 1.02 & 36.22 & BVSN & 42 & 1.16 & 36.92 \\
\hline RCOM & 35 & 0.96 & 37.18 & QCOM & 42 & 1.16 & 38.08 \\
\hline SUNW & 35 & 0.96 & 38.14 & RATL & 41 & 1.13 & 39.21 \\
\hline BRCM & 34 & 0.93 & 39.08 & BRCD & 40 & 1.11 & 40.32 \\
\hline DCLK & 33 & 0.91 & 39.98 & INTC & 40 & 1.11 & 41.42 \\
\hline QCOM & 33 & 0.91 & 40.89 & IWOV & 39 & 1.08 & 42.50 \\
\hline XLNX & 33 & 0.91 & 41.79 & ORCL & 39 & 1.08 & 43.58 \\
\hline \multicolumn{4}{|l|}{2002} & \multicolumn{4}{|l|}{2003} \\
\hline Stock & $\#$ & Percent & Cum. percent & Stock & $\#$ & Percent & Cum. percent \\
\hline QQQ & 145 & 12.80 & 12.80 & QQQ & 63 & 11.03 & 11.03 \\
\hline VRSN & 37 & 3.27 & 16.06 & IIJI & 36 & 6.30 & 17.34 \\
\hline MERQ & 27 & 2.38 & 18.45 & LOR & 24 & 4.20 & 21.54 \\
\hline QLGC & 25 & 2.21 & 20.65 & CHINA & 23 & 4.03 & 25.57 \\
\hline AMAT & 23 & 2.03 & 22.68 & AMR & 13 & 2.28 & 27.85 \\
\hline LNOP & 23 & 2.03 & 24.71 & GMAI & 12 & 2.10 & 29.95 \\
\hline INVN & 21 & 1.85 & 26.57 & GILD & 11 & 1.93 & 31.87 \\
\hline WCOM & 21 & 1.85 & 28.42 & NETC & 10 & 1.75 & 33.63 \\
\hline OVER & 20 & 1.77 & 30.19 & VNWI & 9 & 1.58 & 35.20 \\
\hline QCOM & 20 & 1.77 & 31.95 & SINA & 8 & 1.40 & 36.60 \\
\hline TYC & 20 & 1.77 & 33.72 & DIA & 7 & 1.23 & 37.83 \\
\hline INTC & 18 & 1.59 & 35.30 & EBAY & 7 & 1.23 & 39.05 \\
\hline BRCM & 16 & 1.41 & 36.72 & ELN & 7 & 1.23 & 40.28 \\
\hline NVDA & 16 & 1.41 & 38.13 & NVDA & 7 & 1.23 & 41.51 \\
\hline KLAC & 15 & 1.32 & 39.45 & PACT & 7 & 1.23 & 42.73 \\
\hline MSFT & 15 & 1.32 & 40.78 & SOHU & 7 & 1.23 & 43.96 \\
\hline SEBL & 15 & 1.32 & 42.10 & YHOO & 6 & 1.05 & 45.01 \\
\hline DTHK & 14 & 1.24 & 43.34 & AMZN & 5 & 0.88 & 45.88 \\
\hline EMLX & 14 & 1.24 & 44.57 & ASIA & 5 & 0.88 & 46.76 \\
\hline EXPE & 13 & 1.15 & 45.72 & ATS & 5 & 0.88 & 47.64 \\
\hline TRMS & 12 & 1.06 & 46.78 & GIGM & 5 & 0.88 & 48.51 \\
\hline ADRX & 11 & 0.97 & 47.75 & IMCLE & 5 & 0.88 & 49.39 \\
\hline BEAS & 10 & 0.88 & 48.63 & $\mathrm{SMH}$ & 5 & 0.88 & 50.26 \\
\hline BRCD & 10 & 0.88 & 49.51 & THC & 5 & 0.88 & 51.14 \\
\hline ATVI & 9 & 0.79 & 50.31 & EWEB & 4 & 0.70 & 51.84 \\
\hline
\end{tabular}

Notes: The table lists the 25 most actively traded chat room stocks in each sub-sample.

Table 9

Herfindahl indexes.

\begin{tabular}{llll}
\hline & $H_{t}$ Room & $H_{\omega, t}$ Market & Var. Ratio \\
\hline 2000 & 0.0516 & 0.0882 & $0.2406(1.00)$ \\
2001 & 0.0496 & 0.0868 & $0.2039(1.00)$ \\
2002 & 0.0908 & 0.1137 & 22 \\
2003 & 0.0864 & 0.1744 & $0.6893(0.82)$ \\
\hline
\end{tabular}

Notes: The table compares the Herfindahl index of the chat room $H_{t}$ to the market as a whole, $H_{\omega, t}$. The variance ratio (6) has an $F$-distribution with 25 degrees of freedom. $p$-values are in parentheses. The final column is the number of the top 25 performing traders with significantly higher Herfindahl indexes than the market, $H_{j, t}>H_{\omega, t}$. 
We compare this to the market weights again using the variance ratio,

$$
\frac{K H_{t}-1}{K H_{\omega, t}-1} \text {. }
$$

For 2000, in the last column of Table 9, we find that 21 of the 25 most active traders have Herfindahl indexes for the 25 most active stocks that are more concentrated than the market at the 5\% significance level. For 2001, there are 22 traders, in 2002,23 , and in 2003, only 17. The 2003 decline seems to reflect the room's movement away from technology stocks.

In the next section, we determine whether concentrating trading activity in a small number of stocks impacts a trader's profitability.

\section{Persistence of traders and profits}

\subsection{Survivorship}

336 traders posted their trades into the chat room in October 2000. We arbitrarily assign them an experience level of 1. Of these 336 traders, 181 post trades in the next year, April 2001. There are 91 new traders, making a total of 272 posters. There are 86 survivors in 2002 from 2000, 25 have experience just from the year prior and there are 33 new traders. In our last trading month, June-July 2003, only 19 of the original 336 traders are still posting, which is a weekly compound attrition rate of 1.96 percent. 6 traders have 3 years experience, 9 traders have 2 years, and there are 73 new traders. This transition matrix is in Table 10.

Non-traders have lower survival rates than the traders. Of the original 1329 who post comments in the room but do not post trades, only 35 are left at the end of 2003. This is an attrition rate of 2.48 percent per week, substantially higher than among the traders.

Traders surveyed by Lo et al. (2006) have a compound attrition rate of 22 percent per week. They attribute the strong drop-out rate to the 20 percent decline in the NASDAQ in June-July 2002. In the North American Securities Administrators Association (1999) report on day trading, 70 percent of the traders have loss rates which would exhaust their capital in 40 weeks or less. Our trader drop-out rates are much lower by comparison that seems consistent with their expertise.

\subsection{Effect of longevity on profits}

Are surviving traders likely to be successful in the next trading period? Let $\pi_{j, T}$ denote trading profits for trader $j$ in the current trading month. Then regress current month profits on the profits from last year,

$$
\pi_{j, T}=a_{0}+a_{1} \pi_{j, T-1}
$$

The results for this regression for $T=2001,2002$ and 2003 are in Table 9(b). The persistence coefficient $a_{1}$ is significantly positive in two of 3 years and in the pooled regression. Traders surviving into 2001 from 2000 average $\$ 1746$ in profits and keep 63 percent of their profits above the mean. They keep 10 percent of their prior year above average profits in the transition from 2001 to 2002, by far the weakest, and 29 percent from 2002 into 2003. The $R^{2}$ is strong, above 25 percent in each year except 2003 where we have a very small sample. Pooling across all 3 years, survivors average $\$ 1207$ in profits, and they keep 38 percent of their prior year above average profits. This elite group of surviving traders, just 20.1 percent of the entire group of traders, earn 49.6 percent of the profits.

We next see if experience contributes to profits. Let $A_{j, T}$ be the number of years that the trader has posted trades into Activetrader including the current year. We estimate the model

$$
\pi_{j, T}=b_{0}+b_{1} A_{j, T} .
$$

Results are in Table 9(c). We find a weak but positive relationship between profits and experience. $b_{1}$ is positive in 2001, 2002,2003 , and in the pooled regression, even though it is only statistically significant in 2002. Each year of experience results in $\$ 1170$ in profits in 2001, \$559 in profits in 2002, and \$194 in profits in 2003. The declining value of experience over time suggests that learning does plateau at some point. The pooled estimate for 2000-2003 is \$189 per month per year of trading experience.

\subsection{Stock specific experience}

An alternative measure of experience is stock specific. Perhaps traders benefit from trading a particular stock more frequently. If there is stock specific knowledge, we should find that more trades should raise the profitability of the trader $\pi_{j, T} / n_{j, T}$. We measure trade concentration as we did previously using the Herfindahl index,

$$
\frac{\pi_{j, T}}{n_{j, T}}=c_{0}+c_{1} H_{j, T}
$$




\section{Table 10}

\begin{tabular}{|c|c|c|c|c|}
\hline Experience & 2000 & 2001 & 2002 & 2003 \\
\hline \multirow{2}{*}{\multicolumn{5}{|c|}{ (a) Survival }} \\
\hline & \\
\hline 1 & 336 & 181 & 86 & 73 \\
\hline 2 & & 91 & 25 & 9 \\
\hline 3 & & & 33 & 6 \\
\hline 4 & & & & 19 \\
\hline Total & 336 & 272 & 144 & 107 \\
\hline \multicolumn{5}{|l|}{ Non-traders } \\
\hline 1 & 1329 & 602 & 587 & 405 \\
\hline 2 & & 249 & 115 & 87 \\
\hline 3 & & & 91 & 44 \\
\hline 4 & & & & 35 \\
\hline Total & 1329 & 851 & 793 & 571 \\
\hline Year & Constant & $\pi_{j, T-1}$ & $\bar{R}^{2}$ & $J$ \\
\hline \multicolumn{5}{|c|}{ (b) Profit persistence } \\
\hline 2001 & $\begin{array}{l}1746.387 \\
(1.68)\end{array}$ & $\begin{array}{l}0.632 \\
(8.09)\end{array}$ & 0.424 & 91 \\
\hline 2002 & $\begin{array}{l}795.446 \\
(2.70)\end{array}$ & $\begin{array}{l}0.102 \\
(5.63)\end{array}$ & 0.379 & 54 \\
\hline 2003 & $\begin{array}{l}993.474 \\
(1.50)\end{array}$ & $\begin{array}{l}0.292 \\
(1.57)\end{array}$ & 0.087 & 28 \\
\hline $2000-2003$ & $\begin{array}{l}1207.831 \\
(1.92)\end{array}$ & $\begin{array}{l}0.382 \\
(8.11)\end{array}$ & 0.278 & 173 \\
\hline Year & Constant & Experience & $\bar{R}^{2}$ & $J$ \\
\hline \multicolumn{5}{|c|}{ (c) Effect of experience on profits } \\
\hline 2001 & $\begin{array}{l}199.677 \\
(0.11)\end{array}$ & $\begin{array}{l}1170.856 \\
(0.90)\end{array}$ & 0.003 & 272 \\
\hline 2002 & $\begin{array}{l}-403.082 \\
-(0.96)\end{array}$ & $\begin{array}{l}559.897 \\
(2.43)\end{array}$ & 0.040 & 144 \\
\hline 2003 & $\begin{array}{l}701.601 \\
(1.17)\end{array}$ & $\begin{array}{l}194.912 \\
(0.68)\end{array}$ & 0.004 & 107 \\
\hline 2001-2003 & $\begin{array}{l}788.673 \\
(1.38)\end{array}$ & $\begin{array}{l}189.344 \\
(0.56)\end{array}$ & 0.001 & 522 \\
\hline Year & Constant & $H_{j, T}$ & $\bar{R}^{2}$ & $J$ \\
\hline \multicolumn{5}{|c|}{ (d) Trade concentration and profits } \\
\hline 2000 & $\begin{array}{l}546.786 \\
(3.27)\end{array}$ & $\begin{array}{l}685.892 \\
(1.39)\end{array}$ & 0.020 & 94 \\
\hline 2001 & $\begin{array}{l}196.279 \\
(2.01)\end{array}$ & $\begin{array}{l}723.862 \\
(2.76)\end{array}$ & 0.080 & 90 \\
\hline 2002 & $\begin{array}{l}238.098 \\
(2.42)\end{array}$ & $\begin{array}{l}93.421 \\
(0.30)\end{array}$ & 0.003 & 35 \\
\hline 2003 & $\begin{array}{l}277.482 \\
(4.65)\end{array}$ & $\begin{array}{l}-248.551 \\
-(1.51)\end{array}$ & 0.052 & 42 \\
\hline 2000-2003 & $\begin{array}{l}341.996 \\
(4.62)\end{array}$ & $\begin{array}{l}463.389 \\
(2.19)\end{array}$ & 0.018 & 265 \\
\hline
\end{tabular}

Notes: Panel (a) is the transition matrix for trader and non-trader survival. $J$ is the number of traders. Panel (b) estimates the persistence of profits from one trading month $\pi_{j, T-1}$ to the next $\pi_{j, T}$. Panel (c) regresses trader profits on experience. The last panel (d) examines stock specific skill as measured by the Herfindahl index $H_{j, T}$ of trade concentration.

Results for this regression for profitable traders who make at least three trades ${ }^{10}$ during the month are in Table 9(d). The coefficients $c_{1}$ on the Herfindahl index are positive in all trading months and the pooled regression except for the small 2003 sample. The estimate is statistically significant in 2001 and in the pooled regression. Using the pooled estimate, a trader who

${ }^{10}$ If we include the losing traders, the results remain positive but are not statistically significant. 
makes five trades in five different stocks, $H_{j, T}=5 \times(1 / 5)^{2}=0.2$, could raise her profit per trade by $\$ 370$ if she concentrated on a single stock. Each 0.1 increase in the Herfindahl index raises profit per trade by more than $\$ 46$.

This last finding provides a fresh perspective on the familiarity bias literature. ${ }^{11}$ Traders appear to develop expertise trading specific stocks that enhances their profitability. ${ }^{12}$

\subsection{Economic significance}

The economic significance of the profit estimates is certainly open to question. ${ }^{13}$ On the one hand, 46 on a $\$ 25,000$ trade represents only a 0.18 percent additional return. These would be small numbers for buy and hold investors, but they are statistically and economically significant for active traders.

A more convincing case is made by analyzing the most active traders. The upper quintile average 55 trades each over the whole sample, so the gains from concentrated trading, in the aggregate, are over 10 percent in this group on a $\$ 25,000$ trade. As for experience, after the 33 months in the sample, a skilled trader could make $\$ 19$ per trade $\times 55$ trades $\times 33$ months $=\$ 34,485$ over the next 3 years, or almost 20 percent based on the $\$ 198,000$ average portfolio size .

Translating our 64 day sample into a 250 trading day year, the semi-professional active quintile would earn $\$ 3.577$ million, for an annual return of 13.28 percent on the average portfolio.

If this sample of 136 traders is just a random selection of the group of 50,000 identified by Goldberg and Lupercio (2003), the annual income of 10,000 skilled traders like those in the chatroom would exceed $\$ 250$ million.

\section{Conclusion}

Our group of skilled traders has ignored many of the lessons from their finance classes. They trade very frequently; they focus on the same stocks regardless of market conditions. They make no attempt to diversify. In spite of all these errors, nearly 55 percent earn profits after transactions costs. Trading earns them money, and not surprisingly, they trade often.

They are more sophisticated than simple momentum investors. The momentum factor accounts for little of their daily returns. Together with the other Fama-French factors, we estimate a statistically significant $\alpha$ of 0.17 percent per day. Further evidence of their skill can be seen in their ability to earn profits both long and short.

Their knowledge also appears to grow and adapt to market conditions. Traders realize losses quickly and hold their winners 25 percent longer. Traders maintain 38 percent of their profits from 1 year to the next. Each year of experience adds to their profits. Concentrating on a small group of stocks enhances their profitability.

Goldberg (2006) estimates that, even as day trading ranks have thinned, 27 percent of daily volume on the NYSE and NASDAQ comes from semi-professional traders. We hope that this paper has helped to shed some light on this small but important group.

\section{Acknowledgements}

We would like to thank "WallStreetArb" for permission to post a survey in the Activetrader forum and "Suzanne" for providing portions of the 2001 trading logs. Two anonymous referees and seminar participants at CUNY, Simon Fraser and the 13th SNDE Conference in London provided helpful comments.

\section{References}

Amadi, A. Does familiarity breed investment? An empirical analysis of foreign equity holdings. Working Paper, U.C. Davis, 2004.

Angel, J.J., Christophe, S.E., Ferri, M.G., 2003. A close look at short selling on Nasdaq. Financial Analysts Journal 59, 66-74.

Antweiler, W., Frank, M.Z., 2004. Is all that talk just noise? The information content of Internet stock message boards. Journal of Finance 59, 1259-1295.

Barber, B.M., Lee, Y.T., Liu, Y.J., Odean, T., 2009. Just how much do individual investors lose by trading? Review of Financial Studies 22, 609-632.

Barber, B., Odean, T., 2000. Trading is hazardous to your wealth: the common stock investment performance of individual investors. Journal of Finance 55, 773-806.

Barber, B., Odean, T., 2008. All that glitters: the effect of attention and news on the buying behavior of individual and institutional investors. Review of Financial Studies 21, 785-818.

Barber, B.M., Odean, T., Zhu, N., 2006. Systematic noise. Working Paper, U.C. Davis.

Barberis, N., Thaler, R., 2003. A survey of behavioral finance. In: Constantinides, G., Rene Stulz (Eds.), Handbook of the Economics of Finance. North-Holland, Amsterdam, pp. 1053-1128.

Carhart, M.M., 1997. On persistence in mutual fund performance. Journal of Finance 52, 57-82.

Coval, J.D., Hirshleifer, D.A., Shumway, T.G., 2005. Can individual investors beat the market? Harvard NOM Research Paper 02-45.

Dhar, R., Zhu, N., 2006. Up close and personal: an individual level analysis of the disposition effect. Management Science 52, 726-740.

Fama, E., French, K., 1993. Common risk factors in the returns on stocks and bonds. Journal of Financial Economics 33, 3-56.

\footnotetext{
${ }^{11}$ Ivkovic and Weisbenner (2005) find that investors earn an extra 320 basis points on their local holdings, where local is defined by distance to the company's headquarters.

12 These findings are in contrast to the more limited SEC (2000) study that found: "The Staff did not find a correlation between training and profitability or prior trading experience and profitability."

13 We thank an anonymous referee for helping us assess the economic significance of the chat room activity.
} 
Garvey, R., Murphy, A., 2004. Commissions matter: the trading behavior of institutional and individual active traders. Journal of Behavioral Finance 5, 214-221.

Genesove, D., Mayer, C., 2001. Loss aversion and seller behavior: evidence from the housing market. Quarterly Journal of Economics 116, 1233-1260.

Goetzmann, W., Kumar, A., 2004. Diversification decisions of individual investors and asset Prices. Yale ICF Working Paper No. 03-31.

Goldberg, D., Lupercio, A.M., 2003. Down but not out: semi-pro traders endure a third straight down year. Bear Stearns Equity Research, New York.

Goldberg, D., 2006. Birth of the 'Instividual'. Bear Stearns Equity Research, New York.

Graham, J., Harvey, C., Huang, H., 2005. Investor competence, trading frequency, and home bias. NBER Working Paper \#11426.

Grinblatt, M., Keloharju, M., 2001. What makes investors trade? Journal of Finance 56, 589-616.

Huberman, G., 2001. Familiarity breeds investment. Review of Financial Studies 14, 659-680.

Ivkovic, Z., Weisbenner, S., 2005. Local does as local is: information content of the geography of individual investors' common stock investments. Journal of Finance 60, 267-306.

Jordan, D., Diltz, J., 2003. The profitability of day traders. Financial Analysts Journal 59, 85-94.

Jordan, D., Diltz, J., 2004. Day traders and the disposition effect. Journal of Behavioral Finance 5, 192-200.

Kahneman, D., Tversky, A., 1974. Judgement under uncertainty: heuristics and biases. Science 185, 1124-1131.

Kaniel, R., Saar, G., Titman, S., 2008. Individual investor trading and stock returns. Journal of Finance 63, 273-310.

Lehenkari, M., Perttunen, J., 2004. Holding on to the losers: Finnish evidence. Journal of Behavioral Finance 5, 116-126.

Lo, A.W., Repin, D., Steenbarger, B., 2006. Fear and greed in financial markets: a clinical study of day-traders. American Economic Review Papers and Proceedings 95, 352-359.

Massa, M., Simonov, A., 2005. Behavioral biases and investment. Review of Finance 9, 483-507.

Niccolosi, G., Peng, L., Zhu, N., 2009. Do individual investors learn from their trading experience. Journal of Financial Markets, forthcoming, doi:10.1016/j.finmar.2008.07.001.

North American Securities Administrators Association, 1999. Report of the day trading project group. http://wwwnasaa.org/content/Files/ NASAA_Day_Trading_Report.pdf.

Odean, T., 1998. Volume, volatility, price, and profit when all traders are above average. Journal of Finance 53, 1887-1934.

Odean, T., 1999. Do investors trade too much? American Economic Review 89, 1279-1298.

Securities and Exchange Commission, 2000. Special study: report of examinations of day-trading broker-dealers. http://www.sec.govnews/ studies/daytrading.htm.

Shefrin, H., Statman, M., 1985. The disposition to sell winners too early and ride losers too long: theory and evidence. Journal of Finance 40, 777-790.

Van Ness, B.F., Van Ness, R.A., Warr, R., 2005. Nasdaq Trading and Trading Costs, 1993-2002. The Financial Review 40, 281-304.

Vissing-Jorgensen, A., 2003. Perspectives on behavioral finance: does 'irrationality' disappear with wealth? Evidence from expectations and actions. In: NBER Macroeconomics Annual, pp. 139-193. 